\title{
Differences in Fruit Development among Large- and Small-fruited Cultivars of Saskatoon (Amelanchier alnifolia)
}

\author{
Roisin McGarry, ${ }^{1}$ Jocelyn A. Ozga, ${ }^{2}$ and Dennis M. Reinecke \\ Department of Agricultural, Food, and Nutritional Science, University of Alberta, Edmonton, Alberta, \\ Canada T6G $2 P 5$
}

ADDITIONAL INDEX WORDS. saskatoon berry, service berry, june berry, mesocarp, fruit

\begin{abstract}
Fruit growth in saskatoons (Amelanchier alnifolia Nutt.), an emerging horticultural crop across the Canadian prairies, results from development of the mesocarp and the endocarp-locular-ovular structure which includes the developing seeds. Contribution of these tissues to fruit size was assessed using transverse sections of ovaries sampled at six developmental stages among large- and small-fruited cultivars. Mesocarp development was similar among the larger-fruited cultivars (Thiessen, Northline, and Smoky); the number of cells increased rapidly through Stage I [162 to 293 growing degree days (GDDs)] of fruit growth, and cell number increase was minimal during Stages II (293 to 577 GDDs) and III (577 to 747 GDDs). In 'Regent' fruit (a small-fruited cultivar), the maximal rate of cell division was delayed until Stage II and the mesocarp contained fewer cells than the larger-fruited cultivars at harvest maturity. Mesocarp cell enlargement was similar among all of the cultivars studied where cell expansion was maximal during Stage $I$ and continued at a slower rate during Stages II and III. The area of the endocarp-locular-ovular structure was greatest for 'Thiessen' and 'Northline', midrange for 'Smoky', and smallest for 'Regent'. Data suggest that a minimum number of mesocarp cells early in fruit development is required to attain maximal mesocarp size, and that differences in cultivar fruit size are a function of both the mesocarp and the endocarp-locular-ovular structure.
\end{abstract}

The saskatoon shrub (Amelanchier alnifolia Nutt.) native to Canada has potential as a cultivated horticultural crop (St. Pierre, 1992). Comparisons of saskatoon fruit growth among cultivars can offer insight into many horticultural procedures, including breeding and orchard management, but such research has been limited. Fruit size among the cultivars Thiessen, Northline, Smoky, and Regent differs such that 'Thiessen' > 'Northline' > 'Smoky' > 'Regent' at harvest maturity (McGarry et al., 1998).

In many fruit, size is largely a function of cell division in the early stages and cell enlargement in the final stages of fruit growth (Smith, 1950; Westwood et al., 1967). Using saskatoon fruit from natural stands, Olson and Steeves (1982) observed changes occurring within the outer and inner epidermis, hypodermis, and the outer and inner flesh (mesocarp) of the saskatoon fruit wall during development. Cells of the uniseriate outer and inner epidermis approximately doubled in size from anthesis to fruit maturity, while cells of the biseriate hypodermis expanded 4.2 times. The cells in the outer flesh of the mesocarp increased from four to seven layers at anthesis to 10 to 16 layers at maturity, with cells expanding 4.6 times in diameter. The inner flesh of the mesocarp expanded from 10 to 13 cell layers at anthesis to 13 to 17 layers at maturity, with cells increasing 4.5 times in diameter during this period. Olson and Steeves (1982) concluded that fruit enlargement in wild saskatoons occurred as a result of cell division and expansion predominantly

Received for publication 22 May 2000. Accepted for publication 19 Feb. 2001. This paper is a portion of a MS thesis submitted by R.M. Funding from the Alberta Agriculture Research Institute to J.A.O. is gratefully acknowledged. The authors wish to thank L. Hausher for providing the saskatoon orchard used in this study, S. Dalpe for maintenance of the orchard, D. Craig for use of his image analysis system, G. Braybrook for assistance with presentation of the plates, R. Hardin for help with statistical analysis, and F.G. Dennis, Jr., A. Horak, and P. Blenis for editorial assistance. The cost of publishing this paper was defrayed in part by the payment of page charges. Under postal regulations, this paper therefore must be hereby marked advertisement solely to indicate this fact.

${ }^{1}$ Current address: Dept. of Plant Pathology, Plant Science Bldg., Tower Rd., Cornell Univ., Ithaca, NY 14853.

${ }^{2}$ Corresponding author; e-mail: jocelyn.ozga@ualberta.ca. within the outer and inner flesh of the mesocarp. However, the endocarp-locular-ovular area of the fruit, which can comprise > $50 \%$ of the fruit cross-sectional area, was not taken into account in the Olson and Steeves (1982) study.

Characteristic fruit size among apple [Malus sylvestris (L.) Mill. var domestica (Borkh.) Mansf.] (Smith, 1950) and peach [Prunus persica (L.) Batsch (Peach Group)] (Bradley, 1959; Scorza et al, 1991) cultivars results primarily from cell multiplication after pollination. Although fruit size in saskatoon is related to seed number per fruit and total seed fresh weight $(\mathrm{FW})$ per fruit (McGarry et al., 1998), the specific anatomical basis for fruit size differences among large- and small-fruited cultivars has not been determined. Desired fruit characteristics for saskatoons include minimal endocarp-locular-ovular area, including the seeds, and maximal fleshy mesocarp for the fresh and processed fruit markets. Determination of the contribution of the mesocarp and endocarp-locularovular tissues to final fruit size in saskatoon would aid in selection of cultivars and cultural practices that maximize these fruit characteristics. The objectives of this study were to determine the roles of cell number and expansion upon final mesocarp size and the contribution of the mesocarp and the endocarp-locular-ovular structure (which contains the developing seeds) to final fruit size.

\section{Materials and Methods}

Tissues for histological studies were harvested during the 1994 growing season at the Alberta Crop Diversification Centre North, Edmonton, Alberta, Canada. Three shrubs of 'Thiessen' and two shrubs of 'Northline', 'Smoky', and 'Regent' were selected arbitrarily among a block of 6-year-old saskatoon shrubs. These cultivars exhibited synchronous flowering and similar rates of fruit development. Two closed buds, flowers or fruit were harvested from each of 10 arbitrarily selected inflorescences or infructescences per shrub $(n=20)$. Closed buds were collected 15 Apr., flowers at full bloom (anthesis; 14 May), and fruit biweekly thereafter (1 June, 15 June, and 29 June) until the fully mature ripe fruit stage (fruit 
color purple-black; 15 July). Closed buds and flowers (with cataphylls and petals removed, respectively) were vacuum-aspirated overnight in $3.0 \%$ glutaraldehyde fixative in $0.1 \mathrm{~mol} \cdot \mathrm{L}^{-1}$ phosphate buffer ( $\mathrm{pH}$ 6.8), dehydrated in a graded ethanol series (at 30-min intervals for each $15 \%$ increment of ethanol) followed by two changes in propylene oxide, and infiltrated with Spurr's resin (Spurr, 1969). Transverse 1- $\mu$ m-thick sections were cut midway through the ovary and surrounding accessory tissue (hereafter referred to as ovary) of buds and flowers using a glass knife and a ultramicrotome (0m U 2; Reichert, Vienna, Austria), and stained with $0.5 \%$ toluidine blue-O in $0.1 \%$ sodium carbonate $(\mathrm{pH} 11.1)$. Postbloom ovaries were vacuum-aspirated overnight in a 50\% aqueous ethanol solution containing 5\% formalin and 5\% acetic acid, dehydrated in a graded ethanol/tertiary butyl alcohol series (at 2-h intervals for each increment), and embedded in Paraplast Plus paraffin (Oxford Labware, St. Louis, Mo.) (O'Brien and McCully, 1981). Postbloom ovaries were cut midovary into transverse sections $10 \mu \mathrm{m}$ (1 June), $15 \mu \mathrm{m}$ (15 June), and $20 \mu \mathrm{m}$ (29 June and 15 July) thick with a rotary microtome (Spencer Lens Co., Buffalo, N.Y.) and stained with $2 \%$ safranin (O'Brien and McCully, 1981). Increasing the thickness of the sections as the fruit matured and softened was necessary to avoid crushing the tissue.

Four transverse sections per ovary (four ovaries per shrub per sampling date) were viewed through a compound microscope at $10 \times$ objective lens magnification, and the image was relayed through a video camera (solid-state 4 color video camera; Hitachi VK-C350, Hitachi Ltd., Tokyo, Japan) to an attached MacIntosh IIfx computer. Four regions of mesocarp tissue (avoiding vascular bundles) were selected within each section, and the sample area, the number of cells within the sample, and the area per cell were determined using image analysis software NIH 1.5 (National Institutes of Health, Bethesda, Md.).

For the closed bud ovary transverse sections, total mesocarp area and the area consisting of the endocarp, locules, and ovules (the endocarp-locular-ovular structure) were obtained directly using the NIH 1.5 software program. For the flower ovary transverse sections, the diameter of the ovary was measured using an ocular micrometer; the area of the endocarp-locular-ovular structure was estimated by measuring the area of one carpel consisting of the inner epidermis, two locules, and endocarp tissue between and distal to these locules (no mesocarp tissue was included) using the NIH 1.5 software program. The area of the single carpel as described was then multiplied by five to obtain an estimate of the area of the five relatively uniform carpels which made up the total endocarplocular-ovular structure at this stage. For the postbloom ovary transverse sections, the diameters of the total ovary and that of the endocarp-locular-ovular structure were measured using an ocular micrometer and the respective areas were calculated using the equation for a circle. The total amount of mesocarp tissue in the ovary transverse sections was calculated by subtracting the total area of the endocarp-locular-ovular structure from the total area of the ovary transverse section.

The total number of mesocarp cells per ovary transverse section was estimated using the following equation:

total no. of mesocarp cells $=$ (no. cells in subsample/area of subsample) $\times$ total area of mesocarp

Due to the highly irregular patterns of endocarp cells among fruit within each cultivar, quantitation of the endocarp area per fruit was not performed. Instead, the area of the endocarp-locular-ovular structure, which was more consistent among fruit within each cultivar, was measured as described above.
Sampling dates were expressed as heat units (HU) with the following equation:

$\mathrm{HU}=\left[\left(\mathrm{T}_{\max }+\mathrm{T}_{\min }\right) / 2\right]-\mathrm{T}_{\text {base }}$

where $\mathrm{T}_{\max }=$ daily maximum temperature $\left({ }^{\circ} \mathrm{C}\right), \mathrm{T}_{\min }=$ daily minimum temperature $\left({ }^{\circ} \mathrm{C}\right)$, and $\mathrm{T}_{\text {base }}=$ base temperature of $4.4^{\circ} \mathrm{C}$ (an estimate based on values for apple and synchronicity of multiyear growth data for saskatoon). Negative HUs were assigned a value of zero. Cumulative HUs (from 1 Apr.) were used to calculate growing degree days (GDDs) as follows:

$\mathrm{GDD}=\sum_{1}{ }^{\mathrm{n}} \mathrm{HU}$

where $\mathrm{n}=$ days.

The experiment was conducted and data analyzed as a split-plot design, with shrubs within cultivar as the whole plot, sampling date as the split-plot (closed bud, full bloom, and four postbloom stages), and ovaries and transverse sections as samples and subsamples, respectively, nested within sampling date $\times$ shrubs within cultivar. General Linear Model procedures of SAS 6.10(SAS Inst. Inc., Cary, N.C.) were used for statistical analysis. The shrub within cultivar effect was used as the error term for testing for differences among cultivars, and the shrub within cultivar by date effect was used as the error term to test for differences among date and for the date by cultivar interaction.

\section{Results}

During early floral development (18 to 162 GDDs), mesocarp cells within cultivars were similar in size and shape (represented by 'Thiessen' in Fig. 1A and B). By 293 GDDs, each component of the ovary wall became more distinct: cells of the outer and inner epidermis were more compressed, cells within the hypodermis were more rectangular in shape; and cell size and shape within the mesocarp were less uniform(Fig. 1C). By 424GDDs, brachysclereids were abundant in 'Thiessen' fruit(Fig. 1D), infrequent in 'Northline' and 'Smoky' fruit, and absent from 'Regent' fruit (data not presented). The mesocarp cells continued to expand up to harvest maturity (Fig. 1E and F).

The general pattern of saskatoon fruit development, based on total fruit cross-sectional area, was initially slow [closed bud (18 GDDs) to 162 GDDS] and then increased (162 to 293 GDDs; Stage I of fruit development). Fruit growth slowed from 293 to 577 GDDs (Stage II) then increased from 577 GDDs to harvest maturity (747 GDDs; Stage III; Fig. 2A).

At the closed bud stage (18 GDDs), average mesocarp area was larger than the endocarp-locular-ovular area in all cultivars (Fig. 2B and C; see figure legend). However, from 293 to 577 GDDs, the period in which the majority of seed development occurs within the locules, the endocarp-locular-ovular area was two times the size of the mesocarp tissue with one exception, at 424 GDDs the ratio was 2.6 times (average over all cultivars, Fig. 2B and C). By harvest maturity (747 GDDs), the endocarplocular-ovular area was on average only slightly larger than the mesocarp area (Fig. 2B and C, Table 1).

The role of cell number and expansion upon mesocarp size was examined. The number of mesocarp cells per ovary transverse section differed significantly among cultivars, with significantly fewer mesocarp cells present in 'Regent' fruit than in the other cultivars (ANOVA, main effect of cell number $(1000 \times)$ among cultivars across sampling dates; 'Thiessen' (12.0), 'Northline' (12.1), 'Smoky' (14.0); and 'Regent' (8.4); $P<0.05)$. In 'Thiessen', 'Northline', and 'Smoky', the greatest increase in mesocarp cell 


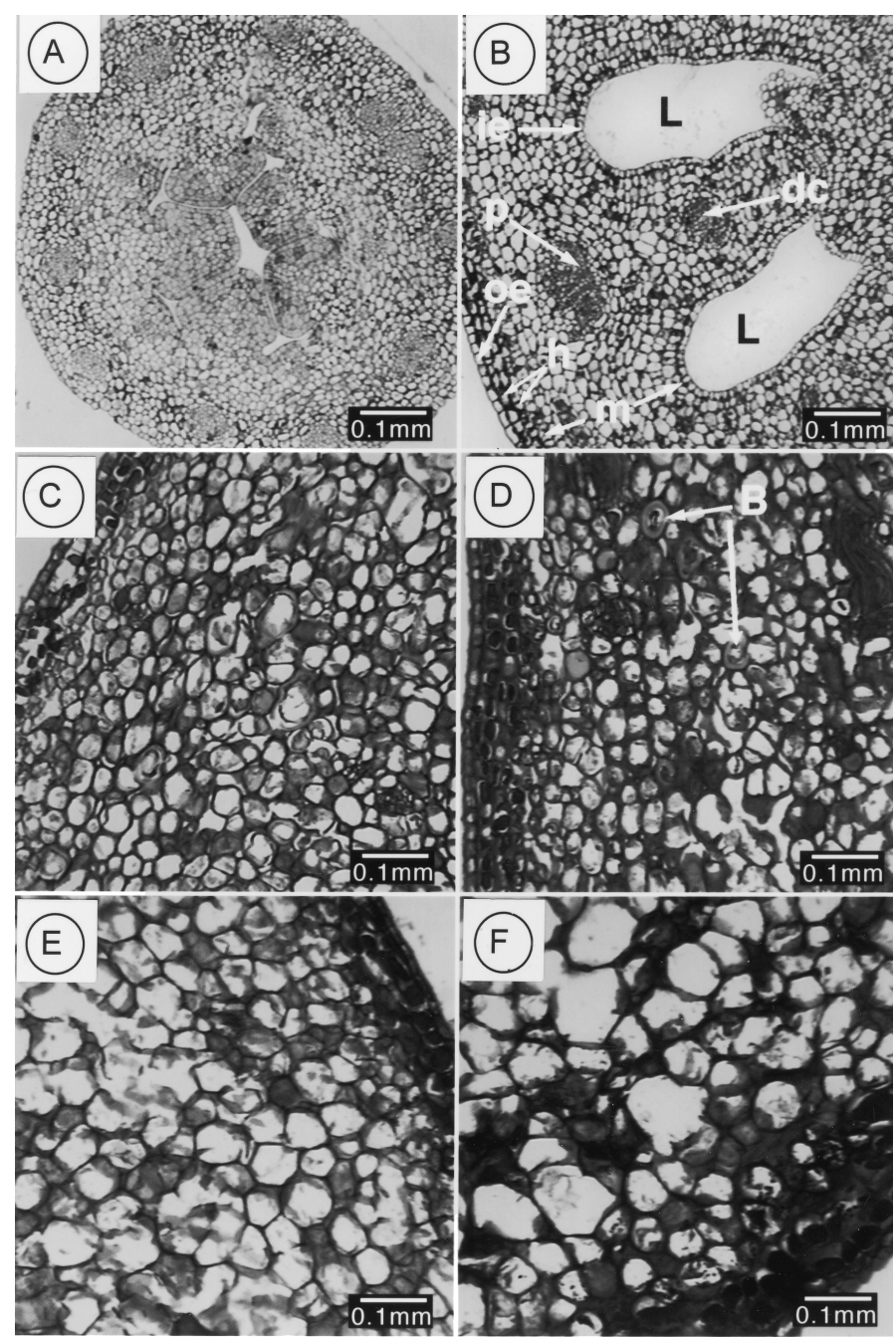

Fig. 1. Light micrographs of transverse sections through the developing ovary of 'Thiessen': (A) 18 growing degree days (GDDs), 15 Apr.; (B) 162 GDDs, 14 May; (C) 293 GDDs, 1 June; (D) 424 GDDs, 15 June; (E) 577 GDDs, 29 June; and (F) 747 GDDs, harvest maturity, 15 July; year 1994. L = locule; ie = inner epidermis; $\mathrm{p}=$ periantho-staminal bundle $; \mathrm{oe}=$ outer epidermis $\mathrm{h}=$ hypodermis; $\mathrm{m}=$ mesocarp $; \mathrm{dc}=$ dorsal carpellary bundle; and $\mathrm{B}=$ brachysclereid.

number per transverse section occurred from 162 to 293 GDDs (Fig. 3A). After 293 GDDs, mesocarp cell number in fruit from 'Thiessen', 'Northline', and 'Smoky' remained relatively constant (Fig. 3A). In 'Regent' fruit, the maximal increase in mesocarp cell number per ovary transverse section occurred later (293 to 424 GDDs) than in the larger-fruited cultivars (Fig. 3A).

The size of mesocarp cells did not vary among cultivars (ANOVA, main effect of cell size among cultivars across sampling dates, $P>0.10$ ). In general, the size of mesocarp cells increased by $0.370 \mu \mathrm{m}^{2} / \mathrm{GDD}$ up to 162 GDDs, and then by 0.996 $\mu^{2} /$ GDD up to 293 GDDs (Fig. 3B). From 293 to 424 GDDs, no increase in mesocarp cell size occurred. The remainder of the fruit development period (424 GDDs to harvest maturity, 747 GDDs) was characterized by continued mesocarp cell expansion (0.43 $\mu^{2} / \mathrm{GDD}$; Fig. 3B).

Fruit of these cultivars were separated into three fruit size classes when the fruit endocarp-locular-ovular area was examined: 1) the largest-fruited cultivars, Thiessen and Northline, 2) the medium-fruited cultivar, Smoky, and 3) the small-fruited cultivar, Regent (Table 1).

\section{Discussion}

Our previous study of saskatoon fruit cultivars showed that 'Thiessen' produced the largest fruit [FW and dry weight (DW)] at harvest maturity, followed by 'Northline', 'Smoky', and 'Regent' (McGarry et al., 1998). Three stages of fruit development were observed in the McGarry et al. (1998) study (based on fruit FW): Stage I (144 to 300 GDDs) was characterized by increasing rates of growth, Stage II (300 to 590 GDDs) by a slower growth rate concomitant with rapid seed development, and Stage III by exponential growth from 590 GDDs to harvest maturity 750 GDDs. Although 'Thiessen' and 'Northline' produced similar-sized fruit at maturity in this study ['Thiessen' was significantly larger than 'Northline' in the McGarry et al. (1998) study], the three phase pattern of saskatoon fruit development observed in McGarry et al. (1998; study based on FW) was also observed in this study (based on the total fruit cross-sectional area; Fig. 2A).

The pattern of mesocarp development with respect to cell number was similar among the larger-fruited saskatoon cultivars (Thiessen, Northline, and Smoky); cell division (as measured by cell number) was most active during Stage I, and minimal during Stages II and III (Fig. 3A). 'Regent', the cultivar which produced the smallest-sized fruit, contained significantly fewer mesocarp cells and did not achieve maximal cell division within the mesocarp until Stage II of fruit growth (Fig. 3A). These data suggest a minimum number of mesocarp cells may be required early in fruit development (Stage I) in order to attain a larger mesocarp area, and contribute to larger fruit size at maturity. Fruit size differences among cultivars result from differences in mesocarp cell number in peach (Scorza et al., 1991), apple (Smith, 1950), avocado (Persea americana Mill.) (Schroeder, 1953), and apricot (Prunus armeniaca L.) (Jackson and Coombe, 1966). Generally, these cell number differences are established during very early fruit development (Bergh, 1985; Smith, 1950). Mesocarp cell number varied during Stages II and III of fruit growth (decreases in cell number per crosssection in 'Theissen', 'Smoky', and 'Regent' during these stages is likely due to variation in fruit size sampled at each harvest date). Nevertheless, in general, the increase in cell number within the saskatoon mesocarp was similar to that in other fruit, where cell multiplication is rapid during early fruit development and then decreases or ceases in the later stages of fruit growth [apple: Blanpied and Wilde, 1968; Tukey and Young, 1942; apricot: Jackson and Coombe, 1966; kiwifruit (Actinidia deliciosa C.S. Liang \& A.R. Ferguson): Hopping, 1986].

The pattern of cell expansion within the mesocarp of saskatoon fruit was similar among the cultivars studied and to that of other fruit species such as apricot (Jackson and Coombe, 1966), avocado (Schroeder, 1953), and kiwifruit (Hopping, 1986), where maximum rates of cell enlargement occur during early fruit development and thereafter expansion continues at reduced rates (Fig. 3B). No increase in mesocarp cell size occurred between 293 and 424 GDDs in all saskatoon cultivars studied (Fig. 3B). This lag in mesocarp cell expansion may be due to a greater allocation of resources to the rapidly expanding endocarp-locular-ovular area (2.6 times greater than mesocarp area at 424 GDDs) during this period. It also is possible that an external event, such as drought stress (slightly dry conditions existed in the orchard at this time), may have contributed to the lag in mesocarp cell enlargement at this time.

We reported previously that saskatoon fruit FW and DW increased linearly with the number of fully developed seeds and the total seed FW per fruit (McGarry et al., 1998). Cultivars with fruit that contained the largest endocarp-locular-ovular and mesocarp 

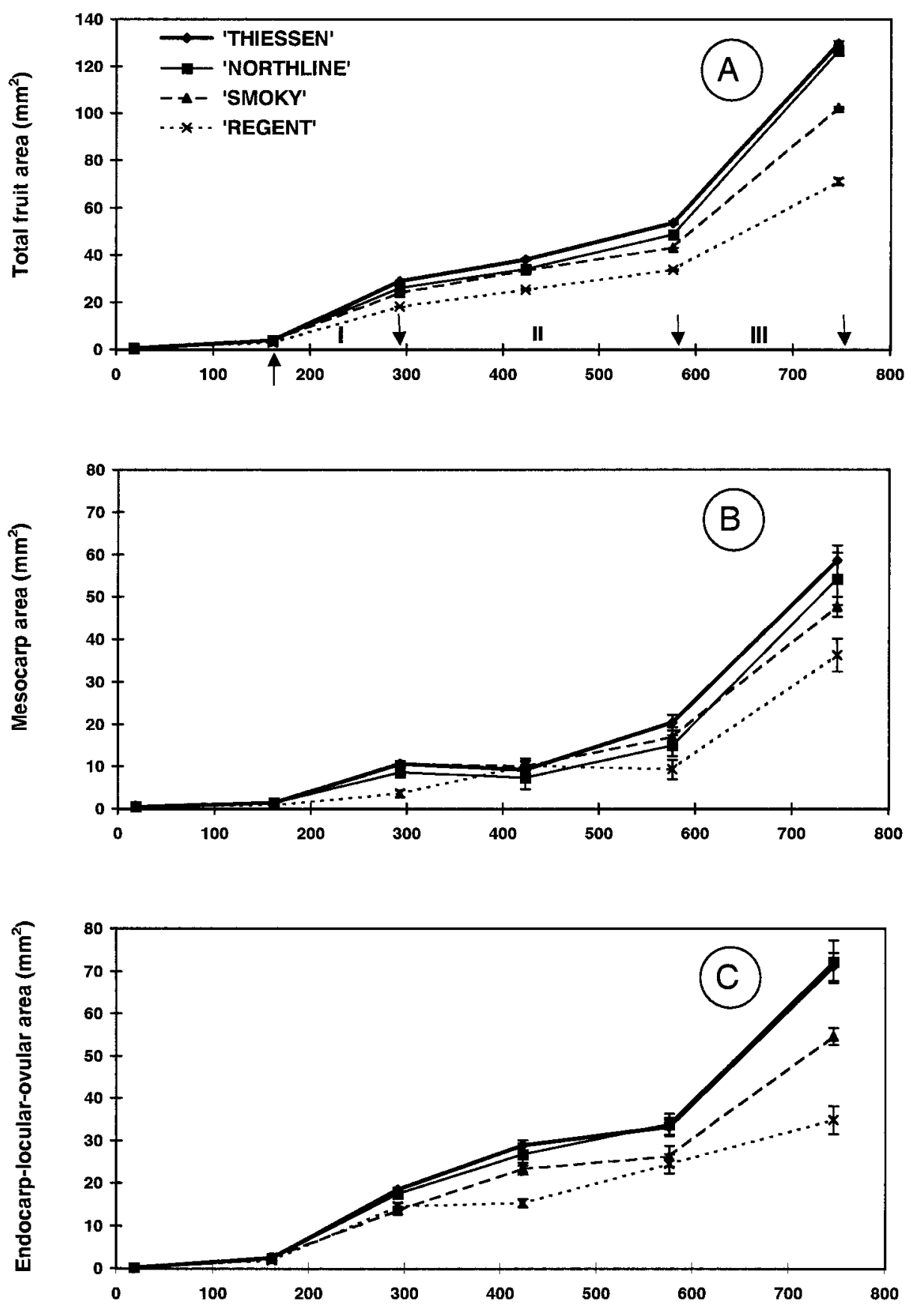

Growing degree days
Fig. 2. (A) Total fruit area, (B) mesocarp area, and (C) endocarp-locular-ovularareaperovary transversesection during 'Thiessen', 'Northline', 'Smoky', and 'Regent' fruit development. For comparison, values for the 18 growing degree days (GDDs) sampling date for $\mathrm{B}$ and $\mathrm{C}$ are as follows: (B) 'Thiessen' $0.429 \pm 0.034$, 'Northline' $0.453 \pm 0.033$, 'Smoky' $0.607 \pm 0.025$, and 'Regent' $0.520 \pm 0.020 \mathrm{~mm}^{2}$; and $(\mathbf{C})$ 'Thiessen' $0.087 \pm 0.006$, 'Northline' $0.087 \pm 0.008$, 'Smoky' $0.121 \pm 0.011$, and 'Regent' $0.157 \pm 0.023 \mathrm{~mm}^{2}$. Vertical bars \pm SE $(\mathrm{n}=8$; exceptfor 'Theissen', $\mathrm{n}=12)$. Stages of fruitdevelopment marked on $x$ axis: I [162 (anthesis) to 293 GDDs], II [293 to $577 \mathrm{GDDs}$ ], and III [ 577 to $747 \mathrm{GDDs}$ ] as described by McGarry et al. (1998).

areas ('Theissen' and 'Northline') also had the greatest seed FW per fruit (seed FW per fruit data from McGarry et al., 1998). Therefore, the number and weight of the seeds per fruit likely contribute to the observed fruit size differences among these saskatoon cultivars by affecting the growth of the mesocarp as well as the area of the endocarplocular-ovular structure by their physical presence.

In summary, our studies indicate that both the mesocarp and endocarp-locularovular areas determine final fruit size in saskatoon and that the number and weight of seeds per fruit affect both parameters. Increases in cell number and expansion in the mesocarp contribute substantially to saskatoon fruit growth early in development (up to 300 to 400 GDDs) and a minimum number of mesocarp cells may be required before 300 GDDs to attain a larger mesocarp area, and contribute to larger fruit size at maturity. Increases in mesocarp size later in development (after 400 GDDs) were due primarily to expansion of existing cells.

Maximizing the mesocarp/endocarplocular-ovular ratio is desirable to obtain fruit with maximal fleshy mesocarps and minimal seeds for the fresh and processed fruit markets. Our studies suggest that several promising areas for future research are possible including the use of plant growth regulators to reduce seed number without significantly diminishing fruit size (McGarry, 1996; Naylar, 1984; Pharis and

Table 1. Areas of the mesocarp, endocarp-locular-ovular structure, and total fruit cross-section from transverse sections of fruit at harvest maturity (747 growing degree days).

\begin{tabular}{|c|c|c|c|}
\hline Cultivar & $\begin{array}{l}\text { Mesocarp } \\
\text { area } \\
(\mathrm{A}) \\
\left(\mathrm{mm}^{2}\right)\end{array}$ & $\begin{array}{c}\text { Endocarp-locular-ovular } \\
\text { structure } \\
(\mathrm{B}) \\
\left(\mathrm{mm}^{2}\right)\end{array}$ & $\begin{array}{c}\text { Total fruit } \\
\text { cross-sectional } \\
\text { area } \\
(\mathrm{A}+\mathrm{B}) \\
\left(\mathrm{mm}^{2}\right)\end{array}$ \\
\hline Theissen & $58.57 \mathrm{a}^{\mathrm{z}}(3.61)^{\mathrm{y}}$ & $71.05 \mathrm{a}(3.30)$ & $129.62 \mathrm{a}(0.95)$ \\
\hline Northline & $54.22 \mathrm{ab}(6.19)$ & 72.19 a (5.03) & $126.41 \mathrm{a}(2.00)$ \\
\hline Smoky & $47.72 \mathrm{~b}(2.35)$ & $54.53 \mathrm{~b}(1.98)$ & $102.25 \mathrm{~b}(0.49)$ \\
\hline Regent & 36.26 c (3.84) & 34.73 c (3.29) & 70.99 c (1.43) \\
\hline
\end{tabular}

${ }^{\mathrm{z}}$ Mean separation within columns by LSD, $P<0.05$.

${ }^{\mathrm{y}}$ Mean $\pm \mathrm{SE}(\mathrm{n}=8$; except for 'Theissen', $\mathrm{n}=12)$. 


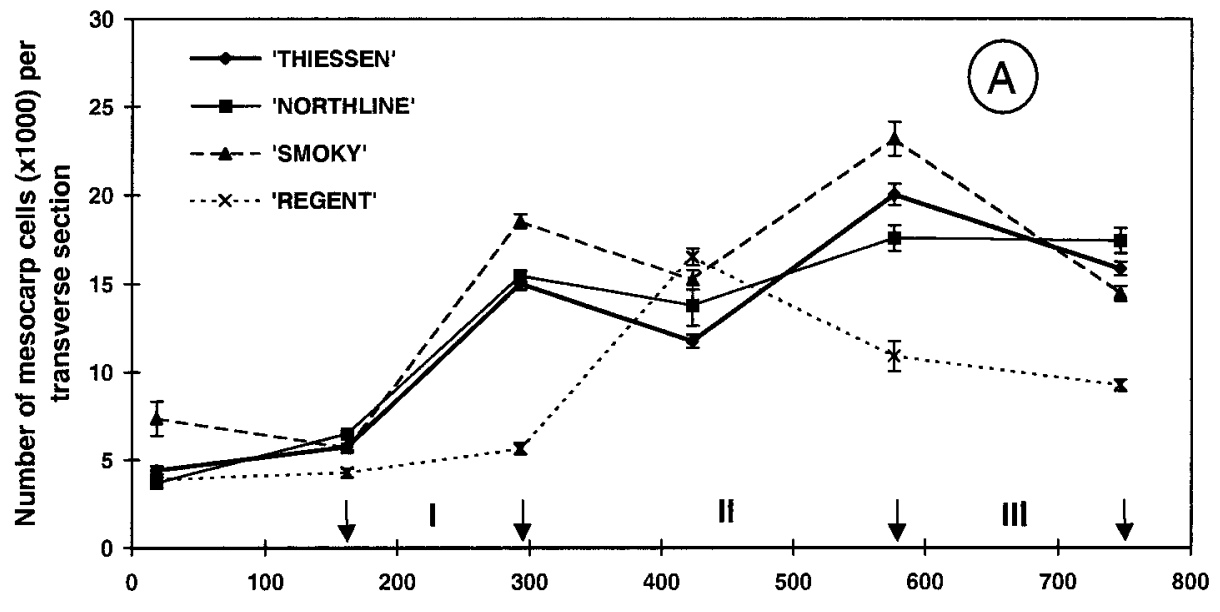

Bradley, M.V. 1959. Mean cell size in the mesocarp of mature peaches of different sizes. Proc. Amer. Soc. Hort. Sci. 73:120 124.

Brown, A.G. 1975. Apples, p. 3-37. In: J. Janick and J.N. Moore (eds.). Advances in fruit breeding. Purdue Univ. Press, West Lafayette, Ind.

Galletta, G.J. 1975. Blueberries and cranberries, p. 154-196. In: J. Janick and J.N. Moore (eds.). Advances in fruit breeding. Purdue Univ. Press, West Lafayette, Ind.

Hopping, M.E. 1986. Kiwifruit, p. 217-232. In: S.P. Monselise (ed.). CRC handbook of fruit set and development. CRC Press, Boca Raton, Fla.

Jackson, D.I. and B.G. Coombe. 1966. The growth of apricot fruit. I. Morphological changes during development and the effects of various tree factors. Austral. J. Agr. Res. 17:465-477.

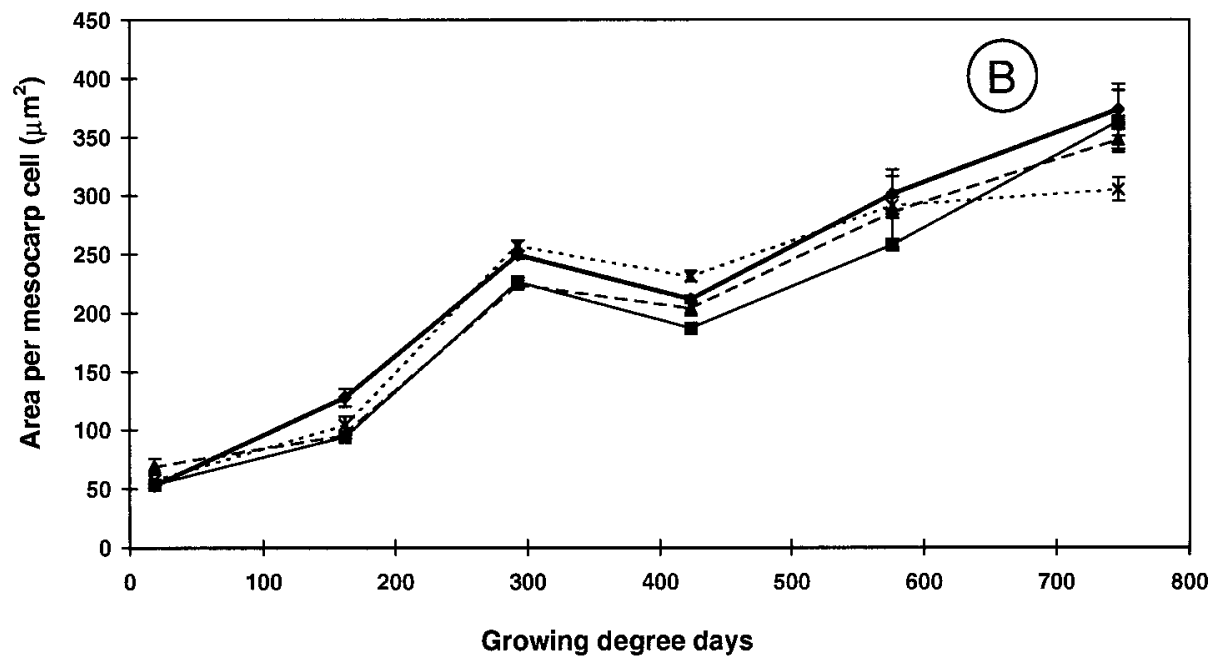

McGarry, R.C. 1996. The role of plant hormones in saskatoon fruit development. MS thesis, Univ. of Alberta, Edmonton, Alberta, Canada.

McGarry, R.C., J.A. Ozga, and D.M. Reinecke. 1998. Patterns of saskatoon (Amelanchier alnifolia Nutt.) fruit and seed growth. J. Amer. Soc. Hort. Sci. 123:2629.

Moore, J.N., B.D. Reynolds, and G.B. Brown. 1972. Effects of seed number, size, and development on fruit size of cultivated blueberries. HortScience 7:268-269.

Naylar, A.W. 1984. Functions of hormones at the organ level of organization, p. 172-218. In: T.K. Scott (ed.). Hormonal regulation of development II. Encyclopedia of plant physiology, (ns). vol. 10. Springer-Verlag, New York.

O'Brien, T.P. and M.E. McCully. 1981. The study of plant structure: Principles and selected methods. Termarcaphi Pty. Ltd., Melbourne, Australia.

Fig. 3. (A) Mesocarp cell number $(1000 \times)$ and $(\mathbf{B})$ mesocarp cell size $\left(\mu \mathrm{m}^{2}\right)$ per
ovary transverse section during 'Thiessen', 'Northline', 'Smoky', and 'Regent' fruit development. Vertical bars $= \pm \operatorname{SE}(\mathrm{n}=8$; except for 'Theissen', $\mathrm{n}=12)$; Stages I [162 to 293 growing degree days (GDDs)], II (293 to 577 GDDs), and III (577 to 747 GDDs) of fruit development as described by McGarry et al. (1998).

King, 1985) and/or to affect early (preanthesis) ovary development [application of gibberellins to tomato (Lycopersicon esculentum Mill.) plants before initiation of floral organs increased ovary size; cited from Pharis and King, 1985]. Alternatively, saskatoons could be bred for large fruit with fewer seeds [exhibited in some blueberry (Vaccinium corymbosum L.) cultivars; Moore et al., 1972], since genotype is often the dominant factor affecting fruit size (Brown, 1975; Galletta, 1975).

\section{Literature Cited}

Bergh, O. 1985. Effect of previous crop on cortical cell number of Malus domestica cv. Starking Delicious apple flower primordia, flowers and fruits. S. Afr. J. Plant Soil 2:191-196.

Blanpied, G.D. and M.H. Wilde. 1968. A study of the cells in the outer flesh of developing McIntosh apple fruits. Bot. Gaz. 129:173-183.

Olson, A.R. and T.A. Steeves. 1982. Structural changes in the developing fruit wall of Amelanchier alnifolia. Can. J. Bot. 60:1880-1887.

Pharis, R.P. and R.W. King. 1985. Gibberellins and reproductive development in seed plants. Annu. Rev. Plant Physiol. 36:517-568.

Schroeder, C.A. 1953. Growth and development of the Fuerte avocado fruit. Proc. Amer. Soc. Hort. Sci. 61:103-109.

Scorza, R., L.G. May, B. Purnell, and B. Upchurch. 1991. Differences in number and area of mesocarp cells between small- and large-fruited peach cultivars. J. Amer. Soc. Hort. Sci. 116:861-864.

Smith, W.H. 1950. Cell-multiplication and cell-enlargement in the development of the flesh of the apple fruit. Ann. Bot. (NS) 14:23-38.

Spurr, A.R. 1969. A low-viscosity epoxy resin embedding medium for electron microscopy. J. Ultrastructure Res. 26:31-43.

St. Pierre, R.G. 1992. The development of native fruit species as horticultural crops in Saskatchewan. HortScience 27:866 and 947.

Tukey, H.B. and J.O. Young. 1942. Gross morphology and histology of developing fruit of the apple. Bot. Gaz. 104:3-25.

Westwood, M.N., L.P. Batjer, and H.D. Billingsley. 1967. Cell size, cell number, and fruit density of apples as related to fruit size, position in cluster, and thinning method. Proc. Amer. Soc. Hort. Sci. 91:51-62. 